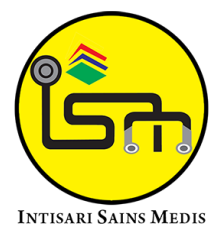

Published by Intisari Sains Medis

\title{
Diagnosis dan penatalaksanaan nodul tiroid tunggal: Sebuah laporan kasus
}

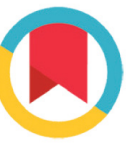

CrossMark

\author{
Nyoman Pramudita ${ }^{1 *}$, Anak Agung Gede Budhi Kusuma ${ }^{2}$
}

\section{ABSTRACT}

Background: Thyroid nodules are abnormal lesions in the form of masses or nodules found in thyroid tissue. Thyroid nodules have a prevalence of about $8 \%$ in the adult population. A single thyroid nodule is asymptomatic and is generally discovered incidentally on physical examination or imaging. Diagnosis is made by physical examination, imaging examination and cytopathological examination. The management of a single thyroid nodule can be done by providing interventional therapy and surgery. The purpose of this case report is to describe the diagnosis and management of a single thyroid nodule case in Wangaya General Hospital.

Case description: A 52-year-old male patient came to the Surgical Clinic at Wangaya General Hospital with complaints of a lump on the left neck in the past eight months. The lump is felt to be enlarged and painless. The patient's diagnosis was confirmed by cytologic examination, which revealed a follicular nodule with a benign tendency. The patient was given surgical therapy in the form of left thyroidectomy.

Conclusion: Single thyroid nodule is quite rare. Treatment of a single thyroid nodule was adjusted according to the results of the cytologic examination. The prognosis for a single thyroid nodule with benign cytology results is generally reasonable. However, it is necessary to follow-up the patient considering the false negative value of the cytological examination.

Keywords: Diagnosis, management, single nodule thyroid

Cite This Article: Pramudita, N., Kusuma, A.A.G.B. 2021. Diagnosis dan penatalaksanaan nodul tiroid tunggal: Sebuah laporan kasus. Intisari Sains Medis 12(3): 677-681. D0I: 10.15562/ism.v12i3.1099

${ }^{1}$ Dokter Magang IImu Bedah RSUD Wangaya, Bali ${ }^{2}$ Staff Dokter Spesialis Bedah RSUD Wangaya, Bali

\footnotetext{
*Korespondensi:
}

Nyoman Pramudita; Dokter Magang IImu Bedah RSUD Wangaya, Bali

pramuditanyoman@yahoo.com

\section{ABSTRAK}

Latar belakang: Nodul tiroid adalah lesi abnormal berupa massa atau nodul yang terdapat dalam jaringan tiroid. Nodul tiroid memiliki prevalensi sekitar $8 \%$ pada populasi dewasa. Nodul tiroid tunggal bersifat asimtomatik dan umumnya ditemukan secara tidak sengaja saat pasien melakukan pemeriksaan fisik atau pencitraan. Penegakan diagnosis dilakukan dengan pemeriksaan fisik, pemeriksaan pencitraan dan pemeriksaan sitopatologi. Penatalaksanaan nodul tiroid tunggal dapat dilakukan dengan pemberian terapi intervensi dan pembedahan. Tujuan pelaporan kasus ini adalah untuk menjabarkan diagnosis dan penatalaksanaan pada salah satu kasus nodul tiroid tunggal di RSUD Wangaya.
Deskripsi kasus: Seorang pasien laki-laki berusia 52 tahun datang ke Poli Bedah RSUD Wangaya dengan keluhan benjolan pada leher kiri sejak 8 bulan yang lalu. Benjolan dirasakan membesar dan tidak nyeri. Diagnosis pasien ini dikonfirmasi melalui pemeriksaan sitologi yang menunjukkan suatu nodul folikular dengan kecenderungan ke arah jinak. Pasien diberikan terapi pembedahan berupa tiroidektomi sinistra.

Simpulan: Nodul tiroid tunggal cukup jarang terjadi. Terapi nodul tiroid tunggal disesuaikan dengan hasil pemeriksaan sitologi. Prognosis nodul tiroid tunggal dengan hasil sitologi jinak umumnya baik, namun perlu dilakukan follow-up terhadap pasien menimbang nilai negatif palsu dari pemeriksaan sitologi.
Kata kunci: Diagnosis, nodul tiroid tunggal, penatalaksanaan

Cite This Article: Pramudita, N., Kusuma, A.A.G.B. 2021. Diagnosis dan penatalaksanaan nodul tiroid tunggal: Sebuah laporan kasus. Intisari Sains Medis 12(3): 677-681. D0I: 10.15562/ism.v12i3.1099 


\section{PENDAHULUAN}

Menurut American Thyroid Association (ATA), nodul tiroid adalah lesi abnormal dalam jaringan tiroid. ${ }^{1}$ Nodul pada jaringan tiroid dapat berjumlah satu atau lebih, berupa kistik, solid, atau campuran dan kadang disertai dengan gejala klinis dari penyakit tiroid. ${ }^{2}$ Nodul tiroid memiliki prevalensi sekitar $8 \%$ pada populasi dewasa dan lebih sering terjadi pada wanita, dimana angka kejadian pada wanita sekitar tiga hingga empat kali lebih tinggi dibandingkan pada laki-laki. ${ }^{3,4}$ Perbedaan ini masih belum diketahui penyebabnya, akan tetapi dicurigai bahwa parameter metabolik dan efek hormon estrogen memegang peranan penting dalam kejadian nodul tiroid. ${ }^{4}$ Angka kejadian nodul tiroid dikatakan meningkat seiring dengan peningkatan umur $(>50$ tahun). ${ }^{5}$ Pada praktik klinis, prevalensi nodul tiroid yang ditemukan melalui pemeriksaan fisik palpasi adalah sebanyak $4 \%$, pemeriksaan ultrasound sebanyak $33 \%$ hingga 68\%, dan melalui otopsi sebanyak kurang lebih 50\%. ${ }^{6}$ Di Amerika Serikat, sekitar 275.000 kasus nodul tiroid baru terdeteksi setiap tahunnya, namun hanya 1 dari 20 nodul yang terpalpasi yang merupakan nodul malignan, dan insiden ditemukannya karsinoma tiroid secara klinis hanya 2 hingga 4 per 100.000 populasi setiap tahunnya. ${ }^{7}$

Nodul tiroid umumnya banyak ditemukan di daerah yang mengalami defisiensi iodin. Paparan terhadap radiasi dikatakan menjadi salah satu faktor risiko, dimana nodul tiroid terjadi sekitar $2 \%$ setiap tahunnya setelah pasien menjalani terapi radiasi. ${ }^{8}$ Sebuah studi retrospektif terhadap pasien dengan penyakit Hodgkin saat masa kanakkanak menemukan bahwa mereka yang menjalani terapi radiasi memiliki risiko 27 kali lebih tinggi untuk mengalami nodul tiroid dibandingkan dengan saudara kandung mereka. ${ }^{9}$ Penelitian lain yang dilakukan terhadap 119 orang penyintas kanker menemukan bahwa mereka yang menjalani terapi radiasi dan kemoterapi memiliki risiko $2 \mathrm{x}$ lebih tinggi untuk mengalami nodul tiroid dibandingkan dengan mereka yang hanya menjalani terapi kemoterapi. ${ }^{10}$

Kebanyakan nodul tiroid bersifat asimtomatik dan ditemukan saat pasien menjalankan pemeriksaan palpasi leher. Namun, terkadang pasien dapat datang dengan keluhan benjolan di leher yang bergerak setiap pasien menelan. Lokasi umum benjolan adalah perbatasan isthmus dengan lobus lateral. Apabila terdapat perdarahan dalam benjolan, pasien akan mengeluhkan benjolan yang dirasa semakin membesar dan rasa nyeri. Pada kasus jinak, benjolan umumnya memiliki permukaan yang mulus, tekstur lembut dengan batas reguler yang dapat jelas terlihat, sedangkan malignansi dapat diprediksi apabila karakteristik tersebut berubah. ${ }^{11}$ Pemeriksaan penunjang berupa pemeriksaan Thyroid Stimulating Hormone (TSH), free thyroxine (fT4), free triidothyronine (fT3), ultrasonografi, dan pemeriksaan needle-biopsy perlu dilakukan untuk menentukan apakah nodul tiroid bersifat jinak atau merupakan malignansi. Penatalaksanaan nodul tiroid dilakukan berdasarkan hasil dari pemeriksaan needle-biopsy. Pada nodul eutiroid yang jinak dan bersifat asimtomatik akan dilakukan follow-up setiap tahunnya dengan melakukan pemeriksaan ultrasonografi dan TSH. Pada beberapa kasus nodul tiroid jinak dapat diberikan intervensi terapeutik seperti pemberian levothyroxine, radioiodine, injeksi etanol, dan pembedahan, khususnya pada nodul tiroid dengan ukuran besar dan memberikan gejala obstruksi. Pada nodul tiroid dengan kecurigaan malignansi, terapi pembedahan merupakan terapi yang disarankan. ${ }^{12}$ Berikut laporan kasus nodul tiroid tunggal yang dikonfirmasi melalui pemeriksaan sitologi dan radiologi.

\section{LAPORAN KASUS}

Pasien laki-laki berusia 52 tahun datang ke Poliklinik Bedah RSUD Wangaya Denpasar dengan keluhan benjolan pada leher sebelah kiri. Benjolan pertama kali disadari sejak 8 bulan yang lalu. Pasien mengaku benjolan di leher awalnya kecil sebesar kelereng dan lama kelamaan semakin membesar hingga sebesar bola pingpong. Benjolan dikatakan tidak nyeri. Pasien tidak pernah berobat sebelumnya. Keluhan lain seperti sesak, gangguan menelan, perubahan suara, dan penurunan berat badan disangkal oleh pasien. Pemeriksaan fisik umum menunjukkan status gizi dan kondisi umum pasien baik. Tanda vital dalam batas normal, tidak ditemukan tanda infeksi seperti peningkatkan suhu tubuh. Pada regio colli anterior sinistra didapatkan benjolan kenyal dengan konsistensi lunak berdiameter $\pm 3 \mathrm{~cm}$. Benjolan ikut bergerak saat pasien menelan dan tidak didapatkan nyeri tekan pada pemeriksaan palpasi.

Pada tanggal 15 Juni 2021, dilakukan pemeriksaan laboratorium dengan hasil pemeriksaan darah lengkap, gula darah sewaktu, urea, kreatinin darah, dan faktor koagulasi didapatkan dalam batas normal. Sebelumnya, pemeriksaan laboratorium juga telah dilakukan pada tanggal 09 Juni 2021, dari pemeriksaan tidak didapatkan peningkatan atau penurunan pada hormon TSH yaitu $1,02 \mathrm{uIU} / \mathrm{mL}$, sementara didapatkan penurunan pada hormon FT4 yaitu sebesar 0,7 ng/dL. USG tiroid menunjukkan adanya nodul solid berukuran $0,61 \times 0,95 \mathrm{~cm}$ tanpa disertai kalsifikasi pada tiroid kanan. Pada tiroid kiri didapatkan ukuran yang membesar dan tampak nodul solid degenerasi kistik yang berukuran $\pm 4,65 \times 3,95 \mathrm{~cm}$ tanpa disertai kalsifikasi dan dengan color doppler ultrasound (CDUS) tidak didapatkan adanya peningkatan vaskularisasi pada parenkim tiroid. Tidak didapatkan pembesaran KGB colli kanan dan kiri serta kelenjar submandibula kanan kiri didapatkan dalam batas normal. Hasil pemeriksaan USG Tiroid disajikan pada Gambar 1.

Pemeriksaan penunjang fine needle aspiration biopsy (FNAB) dilakukan pada benjolan. Gambaran makroskopis menunjukkan nodul soliter pada regio colii anterior sinistra dengan ukuran diameter sekitar $3 \mathrm{~cm}$. Nodul berbatas tegas, konsistensi kenyal dan bergerak saat menelan. Gambaran mikroskopis yang dilakukan dengan pengecatan Diff Kwik menunjukkan apusan mengandung sebaran dan kelompok epitel folikel tiroid yang membentuk struktur lembaran. Sebagian sel epitel folikel tersebut dengan morfologi inti yang monoton, bulat oval dan membran inti reguler. Gambaran sitomorfologi ini mengesankan suatu nodul folikular dengan kecenderungan ke arah jinak, namun belum dapat menyingkirkan malignansi diluar area 


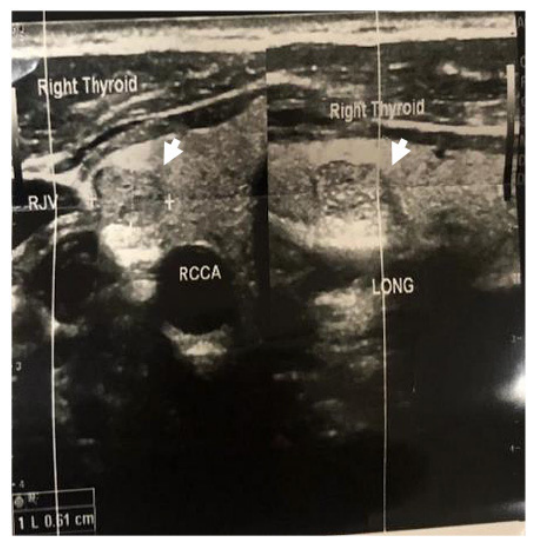

(A)

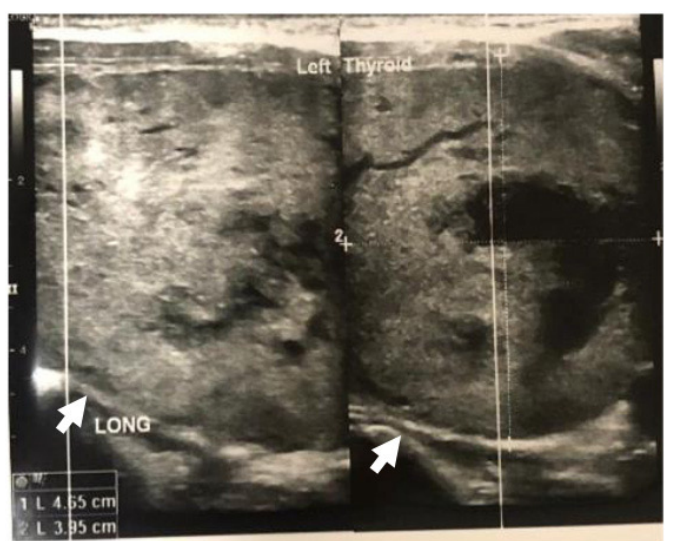

(B)

Gambar 1. (A) Pada USG tiroid kanan menunjukkan nodul solid, isoechoic, dengan batas yang jelas dan tanpa disertai kalsifikasi, sedangkan pada (B) USG tiroid kiri menunjukkan nodul solid degenerasi kistik, isoechoic, berukuran $\pm 4,65 \times 3,95 \mathrm{~cm}$, dengan batas yang jelas dan tanpa disertai kalsifikasi.

pengambilan aspirasi. Berdasarkan anamnesis, pemeriksaan fisik dan penunjang, diagnosis ditegakkan sebagai sebuah nodul tiroid tunggal atau solitary thyroid nodule dan pada tanggal 22 Juni 2021 telah dilakukan tindakan tiroidektomi sinistra.

\section{DISKUSI}

Kelenjar tiroid merupakan salah satu kelenjar endokrin pada tubuh manusia yang terletak di bagian dalam dari otot sternotyhroid dan sterhyoid setinggi vetebra C5 hingga T1. Kelenjar ini memiliki dua lobus, yaitu lobus kanan dan kiri yang terletak anterolateral dari laring dan trakea. Isthmus merupakan bagian yang menyatukan kedua lobus tiroid sepanjang trakea, terletak pada anterior dari cincin trakea kedua dan ketiga. ${ }^{5}$ Sedangkan yang dimaksud dengan nodul tiroid adalah lesi abnormal berupa massa atau nodul yang terdapat dalam jaringan tiroid. ${ }^{1}$ Nodul tiroid memiliki prevalensi sebanyak $5-15 \%$ untuk menjadi malignansi. ${ }^{13}$ Penelitian lain menyimpulkan bahwa gender laki-laki, adanya mikrokalsifikasi dan limfadenopati merupakan faktor risiko dalam memprediksi malignansi pada pasien dengan nodul tiroid tunggal. ${ }^{14}$

Pada kasus ini, pasien merupakan lakilaki, berusia 52 tahun dengan keluhan benjolan pada leher sebelah sejak 8 bulan yang lalu. Benjolan dirasa membesar dan tidak dirasakan nyeri. Pada pemeriksaan fisik pasien didapatkan benjolan kenyal dengan konsistensi lunak berdiameter $\pm 3 \mathrm{~cm}$. Benjolan ikut bergerak saat pasien menelan dan tidak didapatkan nyeri tekan pada pemeriksaan palpasi. Kebanyakan kasus nodul tiroid bersifat asimtomatik dan ditemukan dengan tidak sengaja pada pemeriksaan fisik maupun penunjang. Akan tetapi tak jarang pasien datang dengan keluhan benjolan pada leher. Beberapa gejala seperti kompresi atau obstruksi saluran napas dan disfagia menunjukkan kecurigaan ke arah malignansi dan menunjukkan telah berlangsungnya invasi lokal. Pertumbuhan massa yang terlalu cepat (dalam beberapa minggu-bulan) merujuk pada kasus malignansi. Indikator lain dari malignansi tiroid antara lain nodul yang keras dan terfiksasi, adanya limfadenopati servikal, suara serak, dan ukuran nodul tiroid $>4 \mathrm{~cm} .{ }^{15,16}$ Pada pasien tidak ditemukan suara serak atau adanya limfadenopati servikal sehingga mengurangi kecurigaan yang mengarah ke malignansi tiroid.

Pemeriksaan laboratorium pada nodul tiroid umumnya terdiri dari pemeriksaan fungsi tiroid (TSH, fT4, fT3), ultrasound tiroid, dan pemeriksaan sitologi dengan fine needle aspiration (FNA). ${ }^{12}$ Penurunan pada tiroid stimulating hormone (TSH) dapat menunjukkan nodul dengan hiperfungsi atau toxic goitre, sehingga diperlukan pemeriksaan fT4 dan fT3. Penurunan TSH yang persisten disertai dengan nilai fT4 dan fT3 yang normal dapat menunjukkan hipertiroidisme subklinis, dimana memiliki risiko yang tinggi untuk mengalami atrial fibrilasi dan kerapuhan tulang, terutama pada wanita postmenopause. Sementara, peningkatan TSH atau hipotiroidisme sering disebabkan oleh Hashimoto thyroiditis. Hasil serum TSH yang meningkat atau normal perlu diikuti dengan pemeriksaan ultrasonografi dan pemeriksaan sitologi. ${ }^{17}$ Pada pemeriksaan ultrasound tiroid, temuan nodul kistik, isoechoic, memiliki batas yang tegas dan reguler, tanpa disertai kalsifikasi, dan tidak menunjukkan adanya pertumbuhan yang invasif menunjukkan nodul yang bersifat jinak. Sedangkan temuan nodul solid, hypoechogenic, dengan mikrokalsifikasi, tepi ireguler, pertumbuhan yang invasif dengan lesi multifokal, serta peningkatan aliran darah dalam nodul pada pemeriksaan doppler menunjukkan kecurigaan terhadap malignansi. Insiden malignansi pada nodul tiroid tunggal dengan kalsifikasi dilaporkan mencapai 2,5 kali lebih tinggi dibanding dengan nodul tanpa kalsifikasi. Kombinasi gambaran diatas dapat menunjukkan kemungkinan yang besar adanya malignansi lokal dan metastasis menuju nodul limfa servikal. ${ }^{18}$ Selain itu, studi yang disebutkan oleh Yeung dkk melaporkan bahwa nodul yang memiliki dimensi anteroposterior lebih besar dibanding dimensi transversalnya memiliki kecenderungan untuk menjadi malignan. ${ }^{19}$

Pada kasus ini, hasil pemeriksaan laboratorium pasien menunjukkan hasil TSH yang normal dan penurunan pada fT4 sehingga dilakukan pemeriksaan ultrasonografi. Pada pemeriksaan ultrasonografi pasien didapatkan nodul solid berukuran $0,61 \times 0,95 \mathrm{~cm}$ tanpa disertai kalsifikasi pada tiroid kanan. Pada tiroid kiri didapatkan ukuran yang membesar dan tampak nodul solid degenerasi kistik yang berukuran $\pm 4,65 \times 3,95 \mathrm{~cm}$ tanpa disertai kalsifikasi dan dengan CDUS tidak didapatkan adanya peningkatan vaskularisasi pada parenkim tiroid. Pada USG tiroid pasien, tidak didapatkan gambaran hipo-atau hiperechoic, batas ireguler, ataupun peningkatan vaskularisasi yang mengarah ke malignansi.

Pemeriksaan sitologi dengan metode 
pengambilan sampel menggunakan fine needle aspiration (FNAB) telah diakui sebagai prosedur diagnostik yang akurat, sensitif, dan cost-effective. Fine needle aspiration biopsy untuk malignansi tiroid memiliki sensitivitas antara 65\% hingga 98\% dengan spesifisitas 72$100 \%$ dan tingkat negatif palsu sebesar $1-11 \%{ }^{18}$ Penelitian yang dilakukan oleh Arul dkk mengenai penggunaan pemeriksaan FNAB menunjukkan bahwa pemeriksaan tersebut membantu menurunkan jumlah pasien yang menjalani terapi pembedahan hingga 25$50 \%$, sekaligus meningkatkan persentase temuan malignansi pada grup pasien yang menjalani pembedahan, dimana didapatkan sekitar $5 \%$ pasien dengan nodul tunggal menunjukkan gambaran sitologi yang mengarah ke malignansi. ${ }^{20}$ Pemeriksaan penunjang FNAB pada pasien dilakukan dengan pengecatan Diff Kwik menunjukkan apusan mengandung sebaran dan kelompok epitel folikel tiroid yang membentuk struktur lembaran. Sebagian sel epitel folikel tersebut dengan morfologi inti yang monoton, bulat oval dan membran inti reguler. Gambaran sitomorfologi ini mengesankan suatu nodul folikuler dengan kecenderungan ke arah jinak, namun belum dapat menyingkirkan malignansi diluar area pengambilan aspirasi.

Terapi untuk nodul tiroid tunggal umumnya tergantung dari hasil pemeriksaan FNAB. Selain itu, rencana terapi juga mempertimbangkan usia pasien, jenis kelamin, dan karakteristik dari nodul (ukuran konsistensi, aktivitas, dan jumlah). Pada nodul eutiroid jinak yang asimptomatik biasanya hanya dilakukan observasi dan follow-up pemeriksaan USG dan TSH setiap satu atau dua tahun sekali. Terapi pembedahan menjadi pilihan apabila terdapat hasil pemeriksaan sitologi yang mencurigakan, gejala yang timbul akibat nodul, pasien dengan usia muda, serta pada kasus nodul yang berukuran besar. Pada kasus dengan pemeriksaan sitologi yang mengarah ke nodul jinak, terapi pembedahan tetap disarankan pada nodul dengan ukuran diameter $>4 \mathrm{~cm}$, terdapat tanda dan gejala kompresi, menyebabkan rasa tidak nyaman, dan untuk kepentingan estetika. Pasien dengan hasil sitologi yang jinak dan memiliki faktor risiko yang rendah tetap harus menjalani follow-up selama 12 hingga 24 bulan dengan pertimbangan 5\% false negatifdari hasil fine needle aspiration. Pemeriksaan fine needle aspiration perlu diulangi bila terdapat penumbuhan nodul yang signifikan (penambahan 20\% pada diameter atau dengan penambahan minimal $2 \mathrm{~mm}$ ). Pada pasien post-operasi dengan fungsi tiroid yang normal tidak memiliki indikasi untuk diberikan terapi L-thyroxine rutin. Sementara, pada pasien yang melakukan tiroidektomi total diperlukan pemberian terapi L-thyroxine. Indikasi pembedahan lain pada nodul tiroid jinak meliputi adanya adenoma toksik atau toxic multinodular goiter. Pada kasus nodul tiroid dengan tirotoksikosis, pembedahan dapat dilakukan setelah fungsi tiroid kembali normal. Pasien dengan hasil sitologi malignan harus menjalani tiroidektomi total kemudian diikuti dengan terapi ablasi radioiodine menimbang kemungkinan terjadinya kanker tiroid. Terapi pembedahan memiliki komplikasi meliputi paralisis pita suara unilateral temporer atau permanen, hipokalsemia temporer atau permanen, hematoma, dan infeksi. ${ }^{12}$ Pada pasien dilakukan tiroidektomi sinistra karena ukuran nodul yang besar $(>4 \mathrm{~cm})$ dan telah terjadi degenerasi kistik. Hal ini sesuai dengan hasil penelitian McCoy dkk yang melaporkan bahwa nodul tiroid dengan ukuran lebih atau sama dengan 4 $\mathrm{cm}$ perlu dilakukan terapi pembedahan tanpa memandang hasil dari pemeriksaan fine needle aspiration, hal ini didasarkan pada kemungkinan nilai negatif palsu dari hasil pemeriksaan sitologi. ${ }^{21}$

Nodul tiroid tunggal dengan hasil sitologi yang jinak umumnya memiliki prognosis yang baik. Penatalaksanaan yang tepat dilakukan tidak hanya berdasarkan oleh hasil sitologi namun juga melihat usia, jenis kelamin pasien, dan karakteristik dari nodul itu sendiri. Follow-up perlu dipertimbangkan meski pasien memiliki hasil sitologi jinak menimbang $5 \%$ negatif palsu dari fine needle aspiration. ${ }^{22}$

\section{SIMPULAN}

Nodul tiroid adalah lesi abnormal berupa massa atau nodul yang terdapat dalam jaringan tiroid. Kondisi umumnya bersifat asimtomatik dan lebih sering ditemukan saat pasien melakukan pemeriksaan fisik atau pencitraan. Penegakan diagnosis dilakukan dengan melakukan wawancara medis, pemeriksaan fisik, pemeriksaan laboratorium, pencitraan, dan pemeriksaan sitologi dengan fine needle aspiration. Terapi dari nodul tiroid disesuaikan dengan hasil sitologi, usia dan jenis kelamin pasien, serta karakteristik nodul tersebut. Prognosis nodul tiroid dengan hasil sitologi jinak umumnya baik, namun perlu dilakukan follow-up berkala setiap satu atau dua tahun sekali.

\section{UCAPAN TERIMA KASIH}

Ucapan terima kasih penulis berikan kepada pasien di Poli Bedah RSUD Wangaya dan Bagian/SMF Ilmu Bedah RSUD Wangaya atas kesempatan dan bimbingan yang telah diberikan dalam penulisan penelitian ini.

\section{KELAYAKAN ETIK}

Laporan kasus ini sudah mendapatkan persetujuan pasien dalam keterlibatannya pada laporan kasus ini dan telah memenuhi persyaratan sesuai International Committee of Medical Journal Editors (ICMJE).

\section{KONFLIK KEPENTINGAN}

Penulis menyatakan tidak terdapat konflik kepentingan (conflict of interest) pada penulisan laporan kasus ini.

\section{PENDANAAN}

Penulis bertanggung jawab terhadap seluruh pembiayaan dalam pembuatan laporan kasus ini.

\section{KONTRIBUSI PENULIS}

Penulis bertanggung jawab dalam pembuatan dan penulisan laporan kasus ini.

\section{DAFTAR PUSTAKA}

1. Musa IR, Ahmad ME, Raddady FSA, Rabih WRA, Elsayed EM, Mohamed GB, Gasim GI. Predictors of a follicular nodule (Thy3) outcome of thyroid fine needle aspiration cytology among Saudi patients. BMC Res Notes. 2017;10(621):1-7 
2. Zou B, Sun L, Wang X, Chen Z. The prevalence of single and multiple thyroid nodules and its association with metabolic diseases in chinese: A cross-sectional study. International Journal of Endocrinology. 2020; 2020:1-11.

3. Uyar O, Cetin B, Aksel B, Dogan L, Beksac K, Akgul GG, Berberoglu U, Gulcelik MA. Malignancy in Solitary Thyroid Nodules: Evaluation of Risk Factors. Oncol Res Treat. 2017;40:360-363.

4. Maxwell C, Sipos JA. Clinical Diagnostic Evaluation of Thyroid Nodules. Endocrinol Metab Clin N Am. 2019;48(1):61-84.

5. Sidemen IGAPY. Nodul Tiroid Soliter. E-Jurnal Medika Udayana. 2014;3(8):1-7.

6. Mirfakhraee S, Mathews D, Peng L, Woodruff S, Zigman JM. A Solitary Hyperfunctioning Thyroid Nodule Harboring Thyroid Carcinoma: Review Of The Literature. Thyroid Research. 2013;6(7):1-15.

7. Lansford CD, Teknos TN. Evaluation of the Thyroid Nodule. Cancer Control. 2006;13(2):110.

8. Welker MJ, Orlov D. Thyroid Nodules. American Family Physician. 2003;67(3):559566.

9. Sklar C, Whitton J, Mertens A, Stovall M, Green D, Marina N, Greffe B, Wolden S, Robison L. Abnormalities of the Thyroid in Survivors of Hodgkin's Disease: Data from the Childhood Cancer Survivor Study. The Journal of Clinical Endocrinology \& Metabolism. 2000;85(9):32273232.
10. Agrawal C, Guthrie L, Sturm Ms, Stanek J, Martin L, Henwood-Finley M, Aldrink JH, Olshefski R, O'Brien SH. Comparison of Thyroid Nodule Prevalence by Ultrasound in Childhood Cancer Survivors With and Without Thyroid Radiation Exposure. J Pediatr Hematol Oncol. 2016;38(1):43-48.

11. Goel KS, Goel S. Clinical Approach to Management of Solitary Thyroid Nodule, A Concrete Plan in 42 Patients, in a Tertiary Centre. International Journal of Contemporary Medical Research. 2019;6(3):1-5.

12. Pemayun TGD. Current Diagnosis and Management of Thyroid Nodules. Acta Med Indones-Indones J Intern Med. 2016;48(3):247257.

13. Desser TS, Kamaya A. Ultrasound of Thyroid Nodules. Neuroimag Clin $N \mathrm{Am}$. 2008;18(3):463-478.

14. Monib S, Farkas N, Abdelaziz MI. A Prospective Observational Study Assessing the Relationship Between Solitary Thyroid Nodule Size and Incidence of Malignancy. Cureus. 2020;12(11):1-7.

15. Ghassi D, Donato A. Evaluation of the thyroid nodule. Postgrad Med J. 2009;85(1002):190195.

16. Bomeli SR, LeBeau SO, Ferris RL. Evaluation of a thyroid nodule. Otolaryngol Clin North Am. 2010;43(2):229-238.

17. Wong R, Farrell SG, Grossmann M. Thyroid Nodules: Diagnosis And Management. Med J Aust. 2018;209(2):92-98.
18. Keh SM, El-Shunnar SK, Palmer T, Ahsan SF. Incidence Of Malignancy In Solitary Thyroid Nodules. The Journal of Laryngology \& Otology. 2015;129(7):677-681.

19. Yeung MJ, Serpell JW. Management of the Solitary Thyroid Nodule. The Oncologist. 2008;13(2):105-112.

20. Arul P, Masilamani S. A Correlative Study Of Solitary Thyroid Nodules Using The Bethesda System For Reporting Thyroid Cytopathology. Journal of Cancer Research and Therapeutics. 2015;11(3):617-622.

21. McCoy KL, Jabbour N, Ogilvie JB, Ohori P, Carty SE, Yim JH. The Incidence Of Cancer And Rate Of False-Negative Cytology In Thyroid Nodules Greater Than Or Equal To 4 Cm In Size. Surgery. 2007;142(6):837-844.

22. Ospina NS, Maraka S, Ycaza AEE, Brito JP, Castro MR, Morris JC, Montori VM. Prognosis Of Patients With Benign Thyroid Nodules: A Population-Based Study. Endocrine. 2016;54(1):148-155.

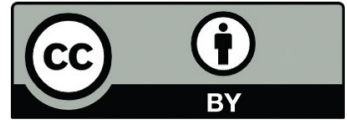

This work is licensed under a Creative Commons Attribution 